\title{
A ESCRITA ESCUTA? ANÁLISE POLIFÔNICA DE RELATÓRIOS DE ESTÁGIO
}

\section{IS WRITING LISTENING? POLYPHONIC ANALYSIS OF INTERNSHIP REPORTS}

Thomas Massao Fairchild ${ }^{1}$

RESUMO: Apresentam-se resultados do projeto de pesquisa (CNPq 458449/20148) sobre o papel da escrita na formaçâo do professor e em sua relaçấo com os conhecimentos. Parte-se da constataçấo de que, mesmo quando relatórios apresentam registros ricos em informaçōes sobre a aula, é raro encontrar análises que as tomem como dados. Levanta-se a hipótese de que essa postura predominantemente descritiva está relacionada à dificuldade de manejar a dimensâo polifônica da linguagem, seja na escuta (ao se observar a aula), seja na escrita (ao produzir um texto sobre a aula). A fim de caracterizar melhor esse problema, adota-se o conceito bakhtiniano de "polifonia" e propóe-se discutir como os estudantes lidam com problemas advindos da necessidade de representar diferentes "vozes" em seu discurso. Pergunta-se: a) se é possível encontrar polifonia em relatórios; b) como podem ser caracterizados textos que năo sâo polifônicos, mas também năo sâo propriamente monológicos; c) como o manejo da polifonia na escrita está relacionado à produçấo de conhecimento sobre a aula. Os dados consistem em excertos extraídos de um corpus de 261 relatórios. As análises resultam em três categorias que descrevem diferentes situaçóes encontradas: o comentário monológico, a hesitaçăo bivocal e o testemunho cacofônico.

PALAVRAS-CHAVE: Escrita no Ensino Superior; Produçăo de conhecimento; Formaçăo de professores; Polifonia.

ABSTRACT: We present results of a research project (CNPq 458449/2014-8) on the role of writing in teachers' education and its relation to knowledge. We start by point out that, according to our work, even when reports present rich information about a class, they seldom bring analyses that use that information as data. Our hypothesis is that this mainly descriptive attitude is related to a difficulty in handling the polyphonic dimension of language, be it in listening (when observing classes), be it in writing (when composing a text on the class). In order to better describe that problem, we adopt Bakhtin's concept of "polyphony" and propose to discuss how students deal with problems deriving from the need to represent different "voices" in their discourse. We ask: a) if it is possible to find polyphony in reports; b) how we can describe some texts that are neither polyphonic nor monologic; c) how handling polyphony in writing is related to the production of knowledge about teaching. Our data consist of excerpts taken from a corpus of 261 internship reports. Our analyses resulted in three

Doutor em Educaçāo e docente da Universidade Federal do Pará, Belém (tmfairch@yahoo.com.br). 
categories that describe different situations found in our data: monologic comments, bivocal hesitation and cacophonic witness.

KEYWORDS: Writing in Higher Education; Production of knowledge; Teachers' education; Polyphony.

\section{INTRODUÇÃO}

As políticas para formaçăo de professores no Brasil vêm assumindo, nos últimos anos, um direcionamento claro com relaçăo às "práticas". As diretrizes curriculares, consolidadas na resoluçâo $\mathrm{CNE} / \mathrm{CP}^{\circ}$ 2/2015, estabelecem como carga horária mínima para as atividades de formaçăo didático-pedagógica $25 \%$ ou um quarto do tempo total de curso nas licenciaturas plenas ${ }^{2}$. Embora a tônica seja a busca por uma articulaçáo entre a teoria e a prática, năo é raro encontrarmos uma interpretaçăo mais incisiva, em que a prática é colocada em relaçăo de exclusăo com outros componentes do currículo. Isso pode ser percebido, a título de exemplo, em uma notícia veiculada no fim de 2015 a respeito das universidades estaduais paulistas:

Um dos principais pedidos de ministros e secretários de Educaçăo começa a ser
atendido por USP, Unesp e Unicamp: cursos que formam professores para o ensino
básico estâo em reformulaçấo, com aumento da carga horária para atividades
práticas. [...] O ministro Aloizio Mercadante e o secretário de educaçáo de SP,
Herman Voorvald, já reclamaram publicamente que os estudantes de pedagogia e
de licenciatura se formam sem saber ensinar, porque tiveram excesso de teoria. [...]
'Os cursos se preocupam mais em formar um físico, um químico, um matemático,
do que um professor', afirmou [Rose] Neubauer. [...] Para o presidente do Consed
(representante de secretários estaduais de Educaçâa), Eduardo Deschamps, 'a
formaçáo dos professores tem sido muito conceitual e teórica. A norma do conselho
parece bem equilibrada (KNAPP, 2012, s/p).

O texto da notícia fornece diversos elementos para uma reflexăo sobre o tratamento conferido às "práticas" na esfera política. Um primeiro ponto é que, pelo menos duas vezes, a notícia confere ao Estado, e năo às comunidades universitárias, o papel de reivindicar mudanças nos processos de formaçăo universitária. Săo os representantes do Estado ("ministros e secretários de Educaçăo", depois nomeados como Aloizio Mercadante e Herman Voorvald) que aparecem fazendo uma espécie de "apelo" ao bom senso dos dirigentes universitários - como se a Universidade tivesse autonomia para opor-se às normatizaçōes que emanam do próprio Estado.

O segundo ponto é que a notícia apresenta o aumento da carga horária dedicada a atividades práticas como uma demanda que só poderia ser realizada por meio de uma diminuiçâo correspondente da formaçāo teórica, nāo só em termos de tempo, mas também em relaçâo aos efeitos formativos visados. Sustentando esse pressuposto está a noçấo de que a teoria pode ser prejudicial ao professor - o problema do "excesso de teoria" (e nâo da "falta de prática") sugere que haveria um limite de tolerância além do qual o conhecimento teórico se tornaria "tóxico", passando a piorar o desempenho do professor em vez de ajudá-lo.

Estamos levando em conta a soma das atividades designadas pelas rubricas "prática" e "estágio", que totalizam 800 h de um total de 3.200h como carga horária mínima do curso. 
Um último ponto é que encontramos na notícia a afirmaçăo de que o Estado năo deseja contratar para o ensino da Física, por exemplo, um profissional que seja um físico, mas algum outro tipo de trabalhador que năo poderia ser designado dessa forma. Se o "professor de Física" náo é um físico, ou ainda, se os físicos năo estăo aptos a dar aula de Física (uma conclusâo compatível), perguntamos: qual é relaçâo suposta entre quem ensina Física e quem trabalha na área da Física?

0 pano de fundo da notícia é a deliberaçâo nº 126/2014, do Conselho Estadual de Educaçâo de Sáo Paulo, que destina uma porcentagem mínima de 30\% da carga horária total dos cursos de formaçăo de professores para a "formaçâo didático-pedagógica" fraçáo ligeiramente maior que a das diretrizes curriculares federais. Nâo queremos avançar num debate sobre esses documentos; desejamos extrair deles, como introduçăo ao problema de nossa pesquisa, algumas hipóteses sobre a natureza das reformas que estamos vivenciando em nossa área. Para esquematizar, tiremos três afirmaçôes possíveis a partir do trecho da notícia que lemos: a) o aumento do componente prático responde a uma demanda originária do Estado e năo da Universidade; b) o aumento da formaçâo prática é um elemento de uma política que visa diminuir a formaçâo teórica do docente; c) essa mesma política visa consolidar a separaçâo entre o profissional encarregado da produçáo do conhecimento e aquele encarregado de sua transmissâo escolar.

O fato de podermos fazer hipóteses como essas basta como justificativa para o problema de pesquisa que apresentamos neste trabalho. Temos nos dedicado há quase dez $\operatorname{anos}^{3}$ a promover uma discussăo sobre a escrita na universidade e, mais particularmente, às relaçóes entre os processos de formaçâo para a docência e as formas que a escrita do docente assume nesses processos. Mais recentemente, começamos a sistematizar essas reflexôes por meio do projeto "A escrita sobre as práticas de ensino em cursos de Licenciatura do Brasil, da Costa Rica e de Honduras: registro, análise e produçấo de conhecimento" (CNPq 458449/2014-8), do qual apresentamos alguns resultados aqui. Essa experiência acumulada nos levou a algumas percepçóes do modo como se escreve nos estágios (e, em alguma medida, também do modo como os estágios săo conduzidos em seu todo) que, neste momento, nos parecem constataçōes bastante seguras.

Nossa avaliaçâo nâo é otimista ${ }^{4}$. A despeito da grande variedade de formas, estilos e nomenclaturas utilizadas nos diferentes cursos, alguns problemas sâo recorrentes na escrita produzida nos estágios. Um deles é a falta de relatos concretos das aulas - é comum, por exemplo, que os conteúdos de ensino sejam mencionados de forma implícita ou registrados de maneira vaga, dando-se ênfase a açōes năo propriamente linguísticas (alguém se levanta, alguém entra na sala etc.) ou a episódios de digressăo e de conflito (conversas fora do tópico da aula, broncas, provocaçōes etc.); também percebemos que o desempenho do professor é registrado com mais frequência que o dos alunos. Como consequência da falta de registros sistemáticos das aulas, as discussóes

Desde que publicamos um primeiro texto problematizando a escrita de estagiários (FAIRCHILD, 2008).

As afirmaçōes que fazemos este parágrafo consistem numa síntese das análises realizadas até o momento no âmbito do projeto mencionado. $\mathrm{O}$ corpus de que dispomos está composto, atualmente, por 261 documentos (relatórios, diários de campo e afins) escritos por estudantes de sete universidades diferentes, sendo cinco delas brasileiras e duas estrangeiras. 
de cunho teórico-metodológico, quando encontradas, aparecem na forma de paráfrases de autores ou documentos oficiais sem remissáo a dados ou, quanto muito, têm um caráter anedótico, incidindo de forma aleatória sobre cenas ou fatos isolados.

Se compararmos essa forma de relatar o que se passa numa aula com a conduta de outros especialistas ao escreverem dentro de seu campo de trabalho (pensemos no etnógrafo, no sociolinguista, no historiador...), somos levados a pensar que o que se faz na aula náo consiste claramente em um trabalho de pesquisa e o modo como se relatam essas açóes nem sempre se caracteriza como um discurso acadêmico. Quando lemos relatórios, em muitos momentos, temos a sensaçâo de estar mais perto de um testemunho oral (ainda que transcrito em uma folha impressa) do que de uma forma do discurso escrito de cunho investigativo.

Temos proposto que se considere que essa forma de escrever năo resulta do acúmulo das fragilidades individuais dos estagiários, mas responde ao papel designado pela universidade ao professor. Ela integra um projeto de formaçăo no qual está previsto que o ato de escrever năo seja, para o docente, instrumento de trabalho intelectual, mas meio para que ele seja avaliado pelas instâncias que reivindicam o controle de sua atividade laboral - dentre elas, o Estado e, sem dúvida nenhuma, a própria Universidade. É claro que a transferência do controle da atividade de ensino do professor para outras instâncias está condicionada à diminuiçâo da autonomia do próprio professor e, sob esse prisma, a precarizaçăo de sua formaçăo teórica, bem como seu confinamento a gêneros escritos que o situam em um foro pessoal em vez de o direcionarem para o diálogo com os pares e com outras comunidades profissionais, exercem um papel importante. É por essa razăo que, segundo pensamos, o Estado pode náo estar interessado em contratar um físico para dar aulas de Física: o professor passa a ser alguém que "gerencia situaçôes didáticas de aprendizagem" ou, se quisermos um ponto de vista mais duro,

[...] a nova identidade do professor é a identidade do capataz, do exercício de uma capatazia, do controle do processo de aprendizagem da criança. Se há um deslocamento, digamos assim, na relaçáo triádica professor, aluno e conhecimento, este deslocamento se dá no tipo de atuaçấo do professor, pois a relaçăo do aluno com o conhecimento náo é mais mediada pela transmissăo do professor, mas sim pelo material didático posto na máo do aprendiz, cabendo ao professor o controle do tempo, da postura e dos comportamentos dos alunos [...]. (GERALDI, 2010, p. 87)

Como nâo estamos confortáveis com essas transformaçôes na identidade docente, vimos nos dedicando também à pesquisa-açăo e à construçăo de práticas, princípios e posturas no ensino da escrita na universidade (especialmente no âmbito da supervisăo de estágios) que possam fazer frente a elas, especialmente no que diz respeito à tendência de desprofissionalizaçăo ${ }^{5}$ da carreira do magistério.

Sobre isso podem-se ver as consideraçôes de Tardif, (2014) para quem o paradoxo da docência consiste em que o movimento pela sua profissionalizaçăo esteja crescendo ao mesmo tempo em que se vive uma "crise do profissionalismo". Todas as características que Tardif associa aos "conhecimentos profissionais" de fato nos parecem fragilizadas quando se pensa na situaçâo dos professores. Discordamos apenas em que o movimento seja, ao menos no Brasil, de profissionalizaçāo - traços que Tardif associa ao conhecimento profissional, como a relaçáo com disciplinas científicas, a exclusáo do leigo e a imputabilidade por "malpractice" (mau uso do conhecimento profissional), parecem estar sendo retirados do professor mais do que reivindicados. 
Neste trabalho, apresentamos uma análise dos resultados que temos obtido em nossas práticas e uma problematizaçáo das dificuldades encontradas para chegar a uma escrita reflexiva. Temos estabelecido como parâmetro fundamental que a prática de estágio seja encarada como uma pesquisa de campo e o relatório resultante, como um texto de cunho científico-investigativo. Devido ao que dissemos há pouco sobre as fragilidades recorrentes na escrita, nosso primeiro objetivo é ensinar o aluno a fazer descriçôes sistemáticas das aulas - condiçăo para que as informaçôes registradas possam ser posteriormente tomadas enquanto dados6. Embora de modo geral consigamos obter dos alunos diários consistentes, temos tido dificuldade de avançar no processo de análise dos registros da aula. Vamos discutir aqui um desses empecilhos, que para nós tem grande abrangência porque toca a relaçâo do sujeito falante com a linguagem: as dificuldades que os alunos encontram, mesmo quando conseguem registrar bem o conteúdo "posto" da aula, de representar as relaçôes dialógicas implícitas nos episódios narrados.

Por nosso interesse nesse problema, temos dado importância ao conceito de "polifonia" e nos perguntamos, ao analisar relatos de estágio, de que formas os estudantes manejam as "vozes" que compóem seu relato. Neste trabalho vamos explorar a noçâo de polifonia desenvolvida por Bakhtin em seu estudo sobre Dostoiévski (2015) - em especial, a noçăo de "discurso bivocal ativo". O problema que levantamos parte da nossa intuiçấo de que os relatos produzidos pelos alunos năo săo exatamente polifônicos (como se poderia dizer da prosa de Dostoiévski), mas também nâo sâo exatamente monológicos (como Bakhtin afirma ser, por exemplo, a prosa de Tolstói).

Fazemo-nos três perguntas, entăo. A primeira: é possível encontrar polifonia (no sentido bakhtiniano) em relatórios de estágio? A segunda, por extensấo: como se pode caracterizar, dialógica ou enunciativamente, a prosa de relatórios de estágios nos casos em que ela nâo é nem polifônica, nem monológica? A terceira, de caráter integrativo: de que maneiras o manejo da polifonia na escrita está relacionado à construçâo de compreensóes da própria "realidade de ensino" construída enquanto tema do discurso?

Acreditamos ter respostas para essas perguntas, mas antes de avançar para isso faremos algumas consideraçóes sobre o modo como concebemos o papel da escrita em relaçăo às práticas de ensino.

\section{A ESCRITA ENQUANTO PRODUÇÃO DE CONHECIMENTO SOBRE AS PRÁTICAS}

Em nossa pesquisa adotamos uma perspectiva discursiva da linguagem e procuramos caracterizar a escrita enquanto atividade dotada de uma dimensâo epistemológica. Consideramos, portanto, que o ato de escrever pode ser encarado enquanto processo discursivo e nos perguntamos, fundamentalmente, como esse processo chega a produzir enunciados nos quais se reconhece a existência de "conhecimento".

\footnotetext{
6 Por exemplo: análises conversacionais de partes da aula; análises textuais ou discursivas de produçōes escritas dos alunos; descriçōes lexicais, fonéticas ou morfossintáticas de excertos da fala de alunos; e assim por diante.
} 
Para que haja "conhecimento", compreendemos que é necessário haver, por um lado, a apropriaçăo individual de um estado de conhecimento dado historicamente e, por outro, um sujeito que age historicamente sobre o estado presente do conhecimento de forma a construir seus estados futuros.

Na análise de relatórios de estágio, essa perspectiva se traduz numa dupla indagaçấo: em que medida os estudantes dâo mostras de estarem aprendendo a respeito de seu ofício (incluindo-se o estado atual das propostas teórico-metodológicas, tanto para agir em aula quanto para dizer o que é ou náo é uma aula) e, ao mesmo tempo, em que medida levantam perguntas e fazem reflexóes que contribuam para o avanço da área (isto é, que levam a novas formas de agir e perceber a aula)? É importante frisar que, quando falamos em avanço da área, năo pensamos apenas no aumento da produçấo acadêmica ou na consolidaçăo de uma ou outra perspectiva - pensamos que o avanço em alguns momentos pode, inclusive, requerer o oposto. Essencialmente, um campo avança năo apenas pelo fortalecimento dos consensos entre aqueles que agem nele, mas também pela capacidade daqueles que ingressam nele de apontar as insuficiências do seu estado de conhecimento atual e, fazendo isso, abrir possibilidades imprevistas de reflexăo e trabalho futuros. Escutar numa aula outras coisas que náo aquilo que os textos lidos na universidade anunciam que se vai escutar, nesse sentido, pode ser uma forma de contribuir para o avanço da área, ainda que dessa escuta resulte, a princípio, apenas uma descriçăo sobre a qual năo se saiba exatamente o que dizer. Esse exemplo, a propósito, serve para ilustrar a importância que damos ao problema da polifonia na produçăo do conhecimento.

Vamos sintetizar nossa perspectiva sobre o papel da escrita por meio de quatro apontamentos esquemáticos. O primeiro - uma aula consiste, para nós, em um acontecimento discursivo. ${ }^{7}$ Materialmente, uma aula é um conjunto de enunciados e pode ser analisada como tal; os enunciados da aula nâo săo "parte" da aula, năo "complementam" nem se "articulam" com "outras dimensóes" da aula (como materiais didáticos, gestos profissionais, tarefas ou quaisquer elementos considerados extra-discursivos) - a materialidade da aula é o próprio discurso que a constitui. Escrever sobre uma aula, nessa perspectiva, năo é uma atividade que esteja em um plano distinto do próprio ato de ministrar a aula - a escrita năo está para aula como o "discurso" está para a "açăo". Escrevendo, produzem-se enunciados de natureza fundamentalmente idêntica aos enunciados produzidos quando se está lecionando em classe e, nesse sentido, escrever é dar seguimento à mesma cadeia discursiva em que se encontram os enunciados da aula propriamente dita. É, ao mesmo tempo, produzir enunciados que respondem aos enunciados originalmente pronunciados no espaço da sala, numa atividade que sustenta o pensamento sobre o ensino e produz novas possibilidades de tomada de posiçăo sobre ele, bem como inaugura possibilidades de açăo didática futura. O diálogo essencial da relaçăo pedagógica năo é um diálogo concreto, entendido como uma conversa presencial - o engajamento com o aluno, a avaliaçăo de seu desempenho, a escuta de suas dúvidas e impulsos, bem como a leitura constante daquilo que se ensina,

Ao dizer isso, inserimo-nos em uma longa tradiçăo de pensamento sobre a Educaçâo existente no Brasil, na qual a aula náo é tomada do ponto de vista didático, enquanto "acontecimento particular" de uma esfera própria (a escola), mas encarada como discurso socialmente produzido. Para uma visāo sintética dessa perspectiva, consulte-se Geraldi (2010). 
a apropriaçăo e o tensionamento dos saberes escolares - esse diálogo nâo se encerra quando bate o sinal; ele se prolonga, com igual ou maior vivacidade, na atividade intelectual subsequente.

Segundo apontamento - a escrita fornece um suporte para essa atividade intelectual do professor sobre sua própria experiência8. Isso acontece na medida em que, relatando o que viu e ouviu na sala de aula, bem como o que disse e fez ouvir, o professor produz (para si mesmo, em primeiro lugar, e para outros) um recorte relativamente objetivável do processo dialógico em que esteve (e ainda está) constituído como sujeito. Grosso modo, escrevendo o que se passou em sala, seja "externamente" (narrando acontecimentos palpáveis e reportando falas literais), seja "internamente" (descrevendo pensamentos e sensaçóes ou procurando dar destaque a entonaçôes e outros aspectos menos explícitos), o professor pode retornar à aula e reviver, em diferentes condiçóes, as "cenas" de que tomou parte. A existência material de um relato escrito, ainda que apenas em esboço, aumenta as chances de se retomar aspectos da aula que, de outra forma, desapareceriam no fluxo ordinário do pensamento - razăo pela qual defendemos que a avaliaçâo direta das práticas do estagiário nâo deveria substituir a avaliaçâo da escrita do estudante sobre suas práticas. Na melhor das hipóteses, a produçăo de um relato detalhado pode fornecer dados para o desenvolvimento de reflexóes analíticas que aumentam a capacidade de compreensăo e tomada de posiçáo do professor frente ao ensino (inclusive o seu próprio ensino).

Em terceiro lugar, a produçâo de um bom relato da aula está diretamente ligada ao desenvolvimento de uma habilidade de escuta. Com isso, estamos dizendo que um relatório de estágio náo nos interessa para avaliar a qualidade da escrita de um estudante (embora possa ser usado para esse fim); a pergunta fundamental năo é "quais sâo as características de um bom relatório?", mas sim "o que se deve esperar que o estudante perceba da aula?". Um aspecto essencial do relato consiste no modo como o estagiário registra em seu texto os enunciados produzidos ali, e a qualidade desse registro depende do modo como esse estagiário "escuta" a si mesmo e aos que falam à sua volta. Uma boa escuta nâo consiste unicamente na capacidade de reproduzir com fidelidade as palavras dos outros, e às vezes nem sequer coincide com isso (veremos adiante que um certo tipo de fidelidade parece resultar da dificuldade de "ouvir"). Acima de tudo, uma boa escuta consiste em perceber as relaçôes "dialógicas" que se estabelecem entre os enunciados - onde há uma fala séria e onde está uma ironia ou um comentário desdenhoso; onde o tom de voz transforma um pedido numa ameaça, uma ordem em um ato de encorajamento, e assim por diante. Essas relaçôes se dăo entre os enunciados produzidos dentro da sala de aula (nas trocas entre o professor e o aluno, na forma de se ler em voz alta um livro didático etc.), mas também entre estes e outros enunciados "externos" à sala (a legislaçâo sobre o ensino em todas as suas formas, as expectativas sociais sobre a escola, a própria universidade representada pelo estagiário etc.).

Enfim, consideramos que a produçâo de um bom relato também está diretamente ligada ao desenvolvimento de um estilo de escrita. Além da capacidade de escuta de que acabamos de falar, o estagiário também precisa se haver com todos os problemas

8 Neste ponto estamos levando em consideraçáo o conceito de "trabalho de escrita" formulado por Riolfi (2011). 
relativos aos modos de expressar, em forma escrita, o que percebeu durante a aula. Pode-se ouvir determinada nuance na fala de um professor - mas como explicá-la, como dá-la a ver a um leitor de forma convincente? Certos episódios quase falam por si; é relativamente simples registrar de forma expressiva, por exemplo, cenas de embate, provocaçóes e conflitos. Mas, para além disso, o registro das trocas cotidianas em sala de aula, com todas as suas sutilezas, demanda um grande esforço estilístico. Se a representaçăo escrita dos estilos de fala de uma época é uma questăo dificilmente resolvida na própria literatura, como vemos na discussăo original de Bakhtin, o que seria um grau de exigência justo para um professor em formaçâo? Procuraremos discutir algumas soluçôes encontradas pelos estagiários e, com isso, chegar mais perto de uma resposta possível. Insistimos em afirmar, em todo caso, que o problema do estilo năo é para nós uma questăo textual, mas epistemológica - a "busca pelas palavras certas" nos interessa na medida em que pode consolidar ou modificar a percepçâo que se tem do objeto do discurso, levando o sujeito a transcender seu próprio lugar de escuta original.

Essa perspectiva tem nos levado a defender que, ao contrário da crença comum, estar dentro da escola - independentemente da quantidade de tempo que se passe ali năo é garantia de se estar em contato com a "realidade da escola". A partir do momento em que se concebe, com Bakhtin, que o signo é ideológico - que ele "nâo existe apenas como parte de uma realidade; ele também reflete e refrata uma outra" (BAKHTIN, 2004, p. 32) -, estar na escola garante nada mais que o contato com as práticas ideológicas da escola, que incluem práticas de produçăo de signos dos quais resulta uma imagem refratada da escola. É nesse sentido que o aumento da carga horária de práticas na formaçăo do professor pode se tornar uma questăo inócua. Formar-se como docente consiste em reunir condiçóes para compreender as práticas escolares inclusive em sua dimensāo refratária da realidade. É necessário, em especial, que o professor se questione acerca do caráter refratário e ideológico de suas próprias práticas escolares, que produzem imagens refratárias dele mesmo. As condiçôes para a interpretaçâo das práticas năo săo dadas a priori. Se a docência exige uma formaçăo prática, esta nâo pode ser projetada como uma etapa meramente instrumental, e menos ainda como uma simples parcela de tempo em que se convive com profissionais mais experientes. Algumas consideraçóes de Michael Apple elucidam a necessidade de uma formaçâo atenta a esse aspecto das práticas escolares.

Um dos problemas que temos que encarar é o da forma através da qual os sistemas de dominaçăo e exploraçăo persistem e se reproduzem sem que isto seja conscientemente reconhecido pelas pessoas envolvidas. [...] Pois "atores conscientes, racionais, bem intencionados" [citando DiMaggio] muitas vezes contribuem - simplesmente pelo fato de perseguir seus próprios fins subjetivos - para a manutençáo dessas relaçóes estruturais [de dominaçăo]. Esses atores conscientes, racionais e bem intencionados, portanto, podem estar, de forma latente, servindo a funçôes ideológicas no momento mesmo em que estăo buscando aliviar alguns dos problemas enfrentados pelos estudantes ou por outras pessoas, individualmente. [...] Assim, podemos analisar as escolas e nossas açôes em relaçáo a elas de duas formas: primeiramente, como uma forma de melhoria e de resoluçăo-de-problemas através das quais ajudamos estudantes particulares a progredir; e, em segundo lugar, numa escala muito mais ampla, detectando quais sáo os padrōes que se formam em relaçăo aos tipos de pessoas que conseguem progredir e quais săo os resultados latentes da instituiçăo. (APPLE, 1989, p. 29-30). 
Apple está se referindo ao problema da produçăo de "desajustamentos" - aos processos ideológicos que legitimam a exclusăo de alguns alunos e o sucesso de outros no aparelho escolar. $O$ que há de importante em seu comentário é a constataçăo de que esses processos náo săo transparentes e seu efeito final pode ser, inclusive, o de ludibriar a consciência dos atores envolvidos neles. Sabendo-se disso, a formaçăo prática do professor nâo pode se reduzir a uma açăo determinada pelos condicionamentos estruturais dos processos escolares; ela deve garantir a ele a possibilidade de produzir novas questóes a partir da suspensâo (ou suspeiçăo) daquilo que se apresenta como óbvio, racional ou objetivo nas relaçôes (ideológicas) de ensino, e inclusive em sua própria consciência. ${ }^{9}$

É particularmente importante para a construçấo desse ponto de vista a ideia de que as relaçóes entre enunciados săo contraditórias e, no limite, impedem que um enunciado possa "explicar" o outro. Essa noçâo pode ser encontrada em diversas formas na Análise do Discurso; ela está originalmente no problema da ilusăo da evidência do sentido ("efeito Munchhausen") e do interdiscurso, em Pêcheux (1995). O conceito de "interincompreensâo" de Maingueneau (2008) também ajuda a descrever esse efeito que năo deixa de afetar a escuta no estágio e a escrita subsequente. Discordamos de Maingueneau apenas na ideia de que a "interincompreensáo" seria um limite intransponível - que realmente nâo se possa, de dentro de um discurso, fazer nada mais que construir "simulacros" dos outros discursos. O próprio Maingueneau nos dá uma evidência em contrário. É que na zona do interdiscurso pode nảo haver somente duas posiçóes - o jansenista, condenado a considerar o humanista leniente; e o humanista, condenado a considerar, com alguma complacência, o jansenista rígido demais. Há uma terceira posiçấo da qual Maingueneau aparentemente se "esquece" - a dele mesmo, enquanto analista, capaz de entender tanto o jansenista quanto o humanista, e ainda explicar por que ambos náo se entendem. Isso é porque, no trabalho de Maingueneau, năo estamos lidando da relaçâo entre dois discursos, mas entre três - o discurso jansenista, o discurso humanista e o discurso da Análise do Discurso. Entre os dois primeiros há "interincompreensăo", mas Maingueneau nâo nos esclarece tanto com relaçăo ao que há entre cada um desses dois e o terceiro. Seja o que for, quando pensamos no estagiário que se póe à escuta da aula, esperamos que ele receba os discursos produzidos aí mais ao estilo de Maingueneau que ao dos sujeitos que ele analisa.

Encontramos em Bakhtin um contraponto ainda mais interessante: se é possível que exista uma coisa como o "romance polifônico", é porque o interdiscurso pode ser, de algum modo, representado no próprio discurso. "O autor năo reserva para si, isto é, năo mantém em sua ótica pessoal nenhuma definiçăo essencial, nenhum indício, nenhum traço da personagem: ele introduz tudo no campo de visăo da própria personagem, lança-lhe tudo no cadinho da autoconsciência" (BAKHTIN, 2015, p. 53). Se Bakhtin afirma isso, é porque acredita que um discurso pode incorporar as palavras de um "outro" sem transformá-las em simulacro e reduzi-las às suas próprias categorias semânticas. É por isso que o herói dostoievskiano é, para Bakhtin, "um ideólogo" que nâo se reduz ao

9 Parece-nos interessante como Apple associa a produçăo dos "desajustamentos" a uma pedagogia da "soluçáo-de-problemas". Uma constataçáo semelhante, mas obtida por outro meio (análise de currículos de cursos de Letras), e mais atual, pode ser encontrada em Pietri e Champoudry (2012). 
"plano do autor" mas, antes, dialoga com este num jogo de consciências "plenivalentes e equipolentes". Como seria possível que o autor desse esse estatuto à personagem se existisse a interincompreensáo e nada mais que ela?

A resposta que nos dá Bakhtin é o esquema geral dos discursos que ele esboça no quinto capítulo ("O discurso em Dostoiévski"), e que representamos de forma simplificada no quadro abaixo.

Quadro 1: Tipos de discurso descritos por Bakhtin em Problemas da Poética de Dostoiévski

\begin{tabular}{|c|c|c|}
\hline \multicolumn{2}{|l|}{$\begin{array}{l}\text { 1. Discurso referencial } \\
\text { Orientado para o obieto }\end{array}$} & \multirow{2}{*}{$\begin{array}{c}\text { Discursos } \\
\text { monovocais }\end{array}$} \\
\hline \multicolumn{2}{|c|}{$\begin{array}{l}\text { 2. Discurso objetificado } \\
\text { Orientado para a pessoa representada }\end{array}$} & \\
\hline \multicolumn{2}{|c|}{$\begin{array}{l}\text { 3. Discurso duplamente orientado } \\
\text { Orientado para o discurso do outro }\end{array}$} & \multirow{4}{*}{$\begin{array}{l}\text { Discursos } \\
\text { bivocais }\end{array}$} \\
\hline - estilização & \multirow{2}{*}{ "passivos" } & \\
\hline - paródia & & \\
\hline - discurso dialógico / "polêmica interna" & "ativos" & \\
\hline
\end{tabular}

Fonte: O autor

Podemos afirmar sobre o quadro acima, de partida, o seguinte: para Bakhtin, existem discursos monológicos (monovocais) e discursos polifônicos (bivocais). O que equivale a dizer: a despeito de a linguagem ser, por princípio, dialógica, pode-se construir um enunciado monológico. Ou ainda, que "monologia" e "polifonia" săo termos que se referem a diferentes possibilidades de se representar, por meio da linguagem, o aspecto dialógico da própria linguagem. Sua argumentaçâo sobre Dostoievski também dá a entender que, em sua visăo, a possibilidade de representar "polifonicamente" o dialogismo inerente à linguagem foi uma construçấo histórica que, no caso dos discursos literários, prolongou-se durante algumas dezenas de séculos - do diálogo socrático e da sátira menipeia até o romance dostoievskiano no fim do oitocentos.

Vamos retomar alguns detalhes do quadro 1 ao longo de nossas análises nas próximas seçōes, por isso nâo nos alongaremos mais aqui. Passamos à exposiçăo dos dados, que está organizada em três tópicos, conforme três estilos ou modalidades de discurso que conseguimos apontar em nosso corpus: o comentário monológico, a hesitaçāo bivocal e o testemunho cacofônico.

\section{O COMENTÁRIO MONOLÓGICO}

A princípio, um dos problemas constatados em nossa pesquisa poderia ser descrito como uma manifestaçâo do discurso monológico. Tem-se de uma tendência a se reduzir a cena de diálogo da aula, com seu dialogismo latente, a um relato monológico "absoluto". Nesse estilo de escrita, uma cena real em que se trava um diálogo a várias vozes (por exemplo, alunos e professores discutem a respeito de uma pergunta que está no livro didático) é representada por meio de uma única voz à qual todas as outras se reduzem. 
(1) A professora se levantou de sua mesa e foi olhar o caderno de cada um dos alunos para saber quem estava fazendo a tar efa que ela complementou com mais três perguntas em sala de aula. Após o termino do trabalho, tempo determinado pela professora. Ela passou outra tarefa valendo ponto, para que eles fizessem em casa. A tarefa consistia em pesquisar sobre um animal de preferência dos alunos. A pesquisa deveria conter: características físicas, comportamentais, nome científico e popular, e os alunos deveriam fazer um desenho do animal escolhido.

O excerto acima consiste na narraçăo de um episódio no qual inferimos a presença de diversos enunciados que poderiam ser transcritos e atribuídos a diferentes locutores, mas o estilo da escrita é tal que descreve esses enunciados sem utilizar, nenhuma vez, os discursos direto ou indireto. Os termos em negrito poderiam ter como referência uma enunciaçăo concreta, mas a representam de forma que a existência do enunciado referido resulta, quando muito, subentendida. Assim, por exemplo, "fazer a tarefa" é um termo com o qual o estagiário se refere ao ato de se escrever determinadas respostas a determinadas questôes no caderno - mas năo há transcriçâo nem de uma coisa, nem de outra. Apenas o trecho sublinhado na parte final do excerto pode ser entendido como sendo uma espécie de registro do conteúdo de um enunciado do professor (as instruçōes de uma tarefa), mas esse conteúdo é parafraseado pelo narrador e nâo apresentado por meio do discurso indireto. Para todos os efeitos, somos levados a ver aí um estilo de escrita que privilegia o monologismo e tende a buscar soluçóes narrativas que neutralizem a presença dos enunciados de outras pessoas, reduzindo-os ao discurso de um narrador uno.

Para além desse efeito de neutralizaçăo, entretanto, o universo dos discursos "monológicos" abarca uma gama mais ampla e sutil de representaçôes do discurso alheio. Bakhtin diferencia, por exemplo, dois polos possíveis do discurso monovocal - o discurso voltado para o referente e o discurso voltado para a pessoa representada. Deixemos de lado o primeiro, que poderia ser exemplificado também pelo trecho (1); vamos observar alguns exemplos do segundo:

(2) A senhora $G$ apontou o dedo para a aluna $G$ e inclinou seu corpo para frente, bem no rosto da aluna, de maneira exaltada pediu para que ela tivesse cuidado com o que diz. Percebi a vice-coordenadora parcial do lado do professor e bastante irritada com os alunos.

(3) A professora falou: Náo acredito! Vocês estăo muitos esquecidos, tăo jovens estăo assim? A prova está chegando, só quero ver o resultado... Bem, com eu havia falado, sujeito é aquele sobre o qual o verbo fala. Por exemplo [...] Três alunos responderam: do sujeito! Isso mesmo crianças. Aqui nós temos o predicado e o sujeito. Aí vocês me perguntaram, como mais de um núcleo? Sim, mais de um núcleo, um, dois, três, quantos vocês quiserem e consigam organizar ali [...].

Aqui temos dois exemplos diferentes de relatos que, citando a palavra do outro, inclinam-se para a representaçăo, em primeiro plano, da "pessoa" que diz essas palavras e apreendem o seu conteúdo referencial apenas de forma secundária. No primeiro caso, tem-se uma descriçâo objetiva do modo como a "senhora G" falou. Curiosamente, o verbo de elocuçăo usado pelo estagiário ("pediu") năo condiz com o modo como seus gestos e tom de voz foram descritos, o que pode ser um indício de que há dois "pontos 
de vista" diferentes concorrendo aí (poderíamos supor que seria mais adequado, mas também mais arriscado, usar verbos como "alertou", "mandou" ou mesmo "ameaçou"). De qualquer maneira, esse parece ser um efeito acidental da escrita.

No excerto seguinte (3) tem-se alguns exemplos de transcriçôes da fala de uma professora em discurso direto nos quais boa parte das palavras (em negrito) prestamse mais a caracterizar o seu tom e estilo do que a acrescentar informaçôes referenciais. Apenas como exercício de análise, imaginemos que o primeiro trecho em negrito poderia ter sido escrito da seguinte forma: "a professora se surpreendeu com o fato de os alunos náo se lembrarem da tarefa e, a seguir, explicou que o sujeito é aquele sobre o qual...". Estaríamos mais próximos do estilo visto em (1), mas nos três exemplos vistos até aqui (salvo por algum efeito de interferência involuntária, de que ainda vamos tratar) nos encontramos diante de discursos monológicos.

Temos que nos perguntar que diferença faz que o estagiário relate a aula de uma forma ou de outra. Deve estar claro que a escrita ao estilo do excerto (1) é problemática porque tende a omitir náo só a caracterizaçāo das "pessoas" representadas no discurso (professores, alunos, e mesmo o ethos presente em textos lidos na sala, nos comandos dos exercícios etc.), mas também o conteúdo preciso de seus enunciados. Os exemplos (2) e (3), por outro lado, nos aproximam de algumas das características mais interessantes do discurso monológico. Bakhtin chega a apontar a possibilidade de discursos objetificados com "predomínio da definiçăo sociotípica" ou com "predomíonio da precisâo caracteriológico-individual" (p. 228) e chega a comentar brevemente obras de Tolstói e Gógol como exemplos de discurso literário monológico. Vejamos o que diz ele a respeito do conto Três mortes, de Tolstói, que ele considera prototípico da narraçâo monológica.

[...] no conto estăo representadas, essencialmente, três vidas, plenamente concluídas em seu sentido e em seu valor. E eis que essas três vidas e os três planos da narraçáo por elas determinados săo interiormente fechados e se ignoram mutuamente. Entre eles há apenas um nexo pragmático exterior, indispensável à unidade temáticocomposicional do conto [...]. Mas todas as três personagens e seus mundos fechados estăo unificados, confrontados e mutuamente assimilados no campo de visáo uno e na consciência do autor, que os abrangem. Ele, o autor, sabe tudo acerca deles [...]. Ele năo fala com ela [a personagem], mas sobre ela. (BAKHTIN, p. 79-80-81).

É verdade que o tom de Bakhtin, ao caracterizar a prosa de Tolstói, é um tanto desfavorável, já que sua definiçấo de "monologismo" é construída como contraponto à tese de que haveria algo diferente em Dostoiévski. Mas Bakhtin năo nega que existe em Tolstói uma análise sociológica eficaz, năo muito diferente daquela que se pode inferir no próprio Dostoiévski; a diferença reside na forma como cada autor a expressa em sua "poética". No caso da escrita universitária, a poética talvez importe menos - seria interessante encontrar com mais frequência boas análises "sociológicas" das práticas escolares, mesmo que essa análise se apresentasse construída em um plano monovocal.

Se voltarmos aos excertos (2) e (3), no entanto, veremos que, embora exista neles um trabalho voltado para a representaçáo da pessoa que fala, essa representaçấo pende para o polo "caracteriológico-individual" e nâo para uma definiçâao "sociotípica" das personagens - podemos imaginar que a "senhora G." estava muito brava naquele momento, ou que a professora do excerto (3) é "simpática" com seus alunos, mas é difícil extrair daí qualquer reflexăo mais consequente. Frisamos que pelo menos alguns tipos 
de caracterizaçăo das personagens da aula envolvem diretamente os conhecimentos específicos do professor de português e, por isso, seriam de se esperar em relatórios de estudantes de Letras - por exemplo, estabelecer se há alunos provenientes de outras cidades ou regiōes do país pelo reconhecimento de características de sua fala, ou reconhecer o alinhamento político dos alunos por meio da leitura de suas redaçóes etc.

Terminemos essa discussăo com um exemplo que consideramos bem sucedido de comentário monológico da aula.

(4) A professora R deu continuidade à aula anterior, sobre níveis de linguagem. Trabalhou com os alunos um texto chamado "Fóscri" (segue em anexo1), aparentemente retirado cópia de um livro didático e de autoria de Renato Pereira. O título "Fóscri" quer dizer "Fósforo" e trabalha, através de um diálogo entre um delegado e um "caipira", dois tipos diferentes de linguagens, a culta e a coloquial, segundo o ensino da professora. Faço uma ressalva aqui, pois a fala coloquial ensinada por ela é, um exemplo de fala caipira, caracterizandose assim, como variaçăo linguística, e năo nível de linguagem.

$[\ldots]$

2. Quais os níveis de linguagem que aparecem na história? Comprove com exemplos do texto.

Resposta da Professora: Săo dois níveis.

- O nível culto, usado pelo narrador e pelo delegado. Exs.: "Era justamente aquela linguagem de caipira que deixava o Pedro Silveira" ou "Entăo o senhor veio dar queixa de três porcas roubadas?"

- O nível popular regional (caipira), usado pelo Pedro Silveira. Exs.: " O sinhô tem fóscri?" ou "Mecê năo píla?"

Aluno B: Nível coloquial: Ora um porco, seu delegado. E o que é que isso tem a ver com o roubo.

Aluno C: Pois é uma porquera sô delegado.

E o que foi que lhe aconteceu?

$[\ldots]$

Náo sei de onde vem a orientaçăo para a professora sobre a fala caipira ser nível coloquial, mas náo concordo com o uso do texto "Foscri" como linguagem coloquial e nem com algumas respostas das questóes dadas pela professora, pois na opçăo A da segunda questăo năo se pode falar em linguagem culta só porque usa uma palavra (justamente) que parece menos usual. Além disso, aprendemos na universidade que isso é variaçăo linguística regional, e o coloquial seria uma conversa entre amigos, as gírias e outros. Ou seja, a opçăo $\mathrm{B}$ da segunda questăo náo poderia colocar como nível de linguagem a fala "caipira", pois ela é uma variaçăo do nosso português brasileiro, e năo uma fala coloquial. Segundo Fiorin [...].

No excerto (4) temos algumas passagens de um longo comentário da estagiária a respeito de uma atividade da professora. Sua posiçấo, basicamente, é a de que a professora está enganada ao considerar que a "fala caipira" seja um "nível de linguagem". As expressōes em negrito săo termos por meio dos quais a estudante demarca a diferença entre seu ponto de vista e aquele sustentado pela professora cujo discurso está sendo relatado. Nâo se trata de um discurso bivocal - o próprio uso dos termos que destacamos em negrito faz com que a divergência entre os pontos de vista da 
estagiária e da professora apareça como um conteúdo explícito do discurso monológico. Nâo há passagens irônicas, insinuaçôes, duplos sentidos ou quaisquer outros efeitos típicos das formas bivocais do discurso (mesmo das que Bakhtin considera passivas). Estamos, por assim dizer, no mundo de Tolstói, no qual as diferenças entre as consciências existem, mas estăo reduzidas ao "plano do autor" - a estagiária reconhece na professora um pensamento teórico e o caracteriza de maneira suficiente, por exemplo, com a transcriçăo da correçâo oral dos exercícios; mas a palavra teórica da professora năo é uma palavra "presente", para usar o termo de Bakhtin - trata-se de uma palavra objetificada.

Como dissemos, este năo nos parece, de modo algum, um mau relatório, mas ao mesmo tempo reconhecemos que nele náo há muito mais do que a redescoberta de uma noçấo que deveria ser simples para o estudante de Letras - a diferença entre variaçăo diatópica e diafásica. Essa constataçăo nos aponta o limite desse relatório e, talvez, do estilo que vimos chamando de comentário monológico. Pode-se supor que existe uma aprendizagem individual no estagiário que escreve um texto assim, mas o produto de sua escrita só é novo, durante algum tempo, para ele mesmo. Nâo há surpresa na posiçăo defendida pelo aluno e pode se esperar que ele mesmo, com o tempo, reconheça em suas palavras o eco de outras palavras ditas muitas vezes antes dele.

Por conta disso temos buscado indícios de outras configuraçóes de discurso que náo a do comentário monológico. No item seguinte, veremos que, quando isso acontece, o resultado final algumas vezes parece um relato pior do que o anterior - o texto assume um tom relutante ou pode mesmo apresentar-se desorganizado e difícil de interpretar. Procuraremos ver o que isso traz de ganhos para o processo reflexivo do aluno.

\title{
A HESITAÇÃO BIVOCAL
}

O discurso bivocal diz respeito, para Bakhtin, a um conjunto de fenômenos em que se incluíam a paródia, a estilizaçăo, o skaz, ou ainda, as formas que ele nomeia como "polêmica interna velada", a "confissāo polemicamente refletida" e outros. Todas essas formas de discurso diferenciam-se do discurso monológico porque nelas a palavra alheia é tomara e investida de tons ou expressōes que a mostram e a modificam. Tratase do discurso "duplamente orientado", em que

\begin{abstract}
a palavra tem duplo sentido, voltado para o objeto do discurso como palavra comum e para um outro discurso, para o discurso de um outro. Se desconhecermos a existência desse segundo contexto do discurso do outro e começarmos a interpretar a estilizaçăo ou a paródia como interpretamos o discurso comum voltado exclusivamente para o seu objeto, năo entenderemos verdadeiramente esses fenômenos: a estilizaçăo será interpretada como estilo, a paródia, simplesmente como má obra. (2015, p. 212)
\end{abstract}

Bakhtin divide os discursos bivocais em dois grandes grupos: de um lado, as formas que ele considera "passivas" e de outro, as "ativas". O discurso bivocal passivo caracteriza-se por considerar a palavra do outro como palavra já-dita, encerrada, sobre a qual se pode construir um posicionamento definitivo. Ele "toma, por assim dizer, a palavra indefesa e sem reciprocidade do outro e a reveste da significaçăo que ele, autor, deseja, obrigando-a a servir aos seus novos fins" (p. 226). Os exemplos mais convincentes dessa 
forma de discurso encontrados nos relatórios do nosso corpus consistem em passagens nas quais percebemos ou ao menos suspeitamos da presença de um tom sarcástico, cujo efeito é o de produzir uma crítica relativamente velada - como na seguinte passagem:

(5) Desta vez, foi a professora que se atrasou a entrar na sala. A campainha tocou duas vezes. Quando a professora entrou, uma aluna, poucos minutos depois, parou à porta querendo entrar. A professora reclamou do atraso da menina (!). Perguntou o porquê de ela estar chegando àquela hora. A aluna respondeu que após o intervalo fora à coordenaçăo. A docente lembrou que desde o primeiro dia avisara sobre o horário. Mas permitiu que a aluna entrasse: “- Da próxima vez...", ainda disse a professora.

Começou entáo a distribuir o novo material (texto de Sérgio Faraco) equivocadamente. Alguém lembrou que nâo havia terminado a atividade anterior. Recolheu o material. Disse que iria corrigir os cadernos e, após isso, dar seguimento à continuaçăo das atividades sobre o texto: Atividade Linguística.

O primeiro trecho em negrito é onde se torna mais claro que o estagiário desdobra sua narrativa em duas vozes. De um lado, está um narrador "neutro", cujo ethos é "sério" e que, pelo menos aqui, limita-se a narrar com suas palavras uma açăo da professora ("reclamar do atraso de uma aluna"). A diferença é que, ao lado desse narrador "neutro", há uma segunda voz que imprime à sua frase um acento particular, registrado pelo uso do ponto de exclamaçâo entre parênteses. Essa segunda voz nâo está presente apenas aí, de fato, mas é ela que orienta toda a organizaçăo das informaçôes na parte inicial do fragmento (5), dando relevo à informaçấo de que a professora se atrasou - por exemplo, com o uso da expressâo "desta vez" e com a afirmaçấo de que a "campainha tocou duas vezes". Da mesma forma, o segundo parágrafo do excerto deve ser lido como um discurso bivocal: no plano explícito, um narrador "neutro" nos informa sequencialmente as próximas açōes da professora, mas as frases curtas e a ausência de conjunçóes constroem, sobre essa aparente neutralidade, um tom de desaprovaçáo.

Por que uma passagem como essa nos parece importante? A resposta que podemos dar vem por meio de um exercício especulativo. A posiçâo expressa pelo estagiário, assim como no excerto (4), năo é em si mesma surpreendente - qualquer um teria condiçóes de reprovar uma pessoa que, após atrasar-se, critica outro que se atrasou um pouco mais. Mas o efeito seria diverso se o estudante manifestasse sua reprovaçăo como parte do conteúdo explícito de seu texto - redigindo, por exemplo, algo como "apesar de a professora ter se atrasado, ela reclamou que uma menina chegou tarde à sua aula, o que nâo deixa de ser contraditório, pois a professora deveria portar-se como exemplo para seus alunos e iniciar a aula pontualmente". Neste caso, e talvez ao contrário do excerto (4), que envolvia uma questăo de fundo teórico, o problema năo requer uma explicaçấ; o simples fato de tentar explaná-lo poderia fazer com que a crítica parecesse fútil.

"Por que razăo há mais beleza em Polyeucte que em 'um trajeto de duas curvas afetado de um movimento para o alto?" - pergunta Derrida (2011, p. 27) sobre a diferença entre a obra literária e a expressâo por meio da qual o crítico a descreve. Sua resposta: "a força da obra, a força do gênio, a força também do que em geral procria, é o que resiste à metáfora geométrica [...]" (DERRIDA, 2011, p. 27). Parece-nos que a escrita do professor precisa também estar dotada de uma "força", pelo menos diante de certos 
tipos de situaçôes. Sem o "(!)" que nos assegura a presença de um segundo olhar do estagiário, pensaríamos que o relatório é ingênuo ou indiferente; a soluçăo estilística encontrada pelo aluno nos assegura de que existe aí uma ressalva. O sarcasmo produz uma resposta eficiente porque evita uma "moralizaçăo" do problema sem deixar que ele passe despercebido. ${ }^{10}$

Até aqui, em todo caso, estamos falando de discursos bivocais "passivos". Resta perguntar se conseguimos encontrar algo semelhante ao discurso bivocal "ativo" em relatórios de estágio e, em seguida, que tipo de movimento do estagiário pode estar sendo indiciado pela ocorrência de passagens assim. Vejamos dois exemplos de relatórios diferentes.

(6) A professora corrigiu em voz alta a atividade do texto "Fóscri" e deu a resposta da questăo 1 como: "O texto fóscri mostra como as pessoas usam a linguagem, mostrando as linguagens diferentes". Năo pude anotar as outras respostas que deu, pois a mesma nos pediu que auxiliássemos os alunos que náo terminaram a atividade do texto "Gente e água - năo dá para separar". 0 que ficou meio confuso para mim, pois se ela estava corrigindo uma atividade em voz alta, como iria auxiliá-los em outra? 0 ideal seria que eles acompanhassem a correçăo, e depois fizessem a outra. Mas também, ela já passou essa atividade há semanas e a correçáo só vem agora, ela dá muito tempo para os alunos e eles só enrolam, penso ser muito tempo perdido em uma atividade. Fomos e auxiliamos os alunos. Muitos náo tinham feito o exercício, o que mostra uma grande falta de interesse dos alunos, que tiveram uma semana para realizarem a tarefa [...].

(7) Nossos comentários sobre o texto giravam em torno da identificaçáo do conflito, da distinçáo da voz do narrador, do reconhecimento da escrita dentro da escrita, recurso conhecido como metalinguagem, da qual eles nunca ouviram falar e tăo cedo ouviriam, pois a professora nos informou que năo se trabalha mais teoria da comunicaçáo nas escolas, conhecimento este restrito apenas aos especialistas do estudo da linguagem. 0 foco agora era outro: abordar os textos em seus contextos de uso (será que foi isso que ela disse mesmo? Năo lembro).

Passagens como estas săo as mais próximas que encontramos da "confissăo polemicamente refletida" de que nos fala Bakhtin. Nos dois casos, a linearidade da narrativa é interceptada por uma segunda linha de raciocínio que dá início a um pequeno diálogo interior. O que há de diferente em relaçâo ao excerto (5) é que aqui o diálogo aparece em curso - é um diálogo "presente", no qual nenhuma das vozes dá uma palavra final em relaçấo à outra (pelo menos dentro de uma certa extensăo do texto). Em (6), o estagiário desenvolve, na parte em negrito, uma crítica ao planejamento da professora, mas esse comentário náo aparece desde o começo como uma posiçâo tomada - compare-se, por exemplo, com o "năo concordo" ou o "aprendemos na universidade" do excerto (4). Pelo contrário, a crítica se constrói no desenrolar de uma troca expressa com outras vozes. Assim, por exemplo, o comentário "nâo pude anotar as outras respostas que deu" é uma

10 Insistimos ainda na complementaridade do excerto (4). Naquele caso năo seria suficiente ironizar a afirmaçáo da professora de que a "fala caipira" é um "nível de linguagem" porque a discordância com relaçáo a esse pensamento requer uma explicaçăo. Se encontrássemos ali um sarcasmo parecido com o de (5), poderíamos suspeitar que se trata de uma crítica arbitrária e o estagiário teria que se defender de uma réplica do tipo "se năo é 'nível de linguagem', como você classifica a 'fala caipira"'? 
resposta à orientaçăo anterior do supervisor de estágio de que anotassem todas as respostas dadas pelos professores nas correçōes dos exercícios; o próprio trecho "o que ficou meio confuso para mim...", até a pergunta ao fim da frase, dá continuidade a essa justificativa. Logo a seguir, porém, o trecho que começa com "mas também..." introduz um contraponto à crítica iniciada, que poderia ser parafraseado como "se a professora passou a atividade, é melhor corrigi-la logo do que deixa-la sem correçâo ou perder ainda mais tempo com isso" - o que consiste numa revisăo da posiçăo expressa na frase "ficou meio confuso para mim".

O trecho (7) é um pouco mais complicado, e de fato pode-se ter dúvida sobre o que ele quer dizer. Trata-se do relatório de uma aula de regência, de modo que há aí relatos da própria fala do estagiário e também o registro de um comentário da professora. Tem-se a impressăo de que o primeiro trecho em negrito é a topicalizaçăo do conteúdo semântico de um enunciado do estagiário - um resumo da explicaçâo que deu em aula. A parte sublinhada logo a seguir, no entanto, pode ser interpretada tanto como pertencendo à fala do estagiário quanto como sendo já uma paráfrase do conteúdo do comentário da professora. O segundo trecho em negrito deve ser um registro do enunciado da professora, mas seria possível que uma parte dele já consistisse, agora ao inverso, em uma resposta do estagiário, um comentário que ele acrescenta às palavras da professora sem marcar exatamente o ponto de corte.

Nossa tendência é interpretar todo o trecho (7) como uma espécie de polêmica interiorizada do estagiário com a professora. Esta, ao que parece, interrompeu ou interveio na explicaçấo do estagiário para dizer aos alunos que o assunto de que ele tratava nâo pertencia ao seu currículo, por ser obsoleto ou excessivamente especializado. Pode-se imaginar que trechos como "nunca ouviram falar e tâo cedo ouviriam", ou "o foco agora era outro: abordar os textos em seus contextos de uso", guardam um pouco do tom com que essa intervençâo foi feita. Nesse caso, a conclusăo que tiraríamos é a de que o estagiário está fazendo uma espécie de relato irônico de uma interrupçáo da professora em sua aula, que ele considerou impertinente. O comentário entre parênteses ao final pode ser entendido como uma acentuaçáo dessa ironia ou como uma contraposiçâo a ela - na primeira hipótese, chegaríamos a uma forma mais passiva de bivocalidade (todo trecho seria irônico); na segunda hipótese, teríamos um diálogo aberto, uma oscilaçăo no arranjo inicial das vozes, e estaríamos mais próximos do discurso bivocal ativo (a ironia inicial seria contrabalançada por uma dúvida "sincera" sobre o papel da intervençấo da professora).

O que colocamos até aqui nâo quer dizer que trechos como (6) e (7) săo "melhores" enquanto relatos do que os que vimos na seçăo anterior. Temos que considerar que comentários de cunho monológico pode resultar de movimentos dialógicos semelhantes aos que vimos aqui, mas deliberadamente apagados do texto final. Ao mesmo tempo, em (6) e especialmente em (7), năo conseguimos dizer até que ponto a presença de diferentes vozes e tons resulta de um trabalho do autor ou de algum efeito de eco ou transposiçáo que transfere para o texto traços de um acontecimento dialógico "real" que existiu, de fato, antes do texto (nâo há paralelo para isso no caso do romance polifônico). Essa dúvida nos levará ao terceiro caso de análise. Antes disso, no entanto, resumimos nossos apontamentos sobre o discurso bivocal: a) as variedades "passivas" parecem ilustrar algumas possibilidades interessantes de comentário e posicionamento do estagiário com relaçaáo à aula, que concorrem com as explicaçôes e análises 
de cunho mais racional (monológico); b) as variedades "ativas" podem estar dando testemunho de hesitaçóes e revisōes importantes para que o estagiário rompa imagens pré-estabelecidas da escola; o registro dessas hesitaçôes na escrita pode ser ponto de partida para uma mudança de posiçăo mais consistente.

\section{O TESTEMUNHO CACOFÔNICO}

Mesmo dentro dos enunciados que consideramos monológicos, indicamos alguns pontos em que podíamos ao menos suspeitar da intercessâo de outras vozes implicitamente afetando o discurso do narrador. Chegamos a dizer que essa interveniência seria um efeito involuntário da escrita. De modo semelhante, nos discursos que consideramos bivocais ativos, também ficamos na dúvida se estamos diante de um diálogo do autor com outras vozes ou se nós mesmos, como leitores, nos colocamos em diálogo com essas vozes que o autor apenas justapóe à sua ao compor seu texto. Resta agora definir melhor do que se trata essa possibilidade para a qual vimos apontando.

Dissemos antes que os relatórios em alguns momentos nâo parecem ser nem polifônicos, nem exatamente monológicos. Trata-se de passagens em que o discurso permite reconhecer a existência de diferentes vozes sem que se consiga estabelecer com certeza quais sâo as relaçôes dialógicas que as articulam. $O$ excerto abaixo é um exemplo disso.

(8) Segundo o professor $\mathrm{K}$ os alunos desta turma escreviam pouco e o discurso direto e indireto era um assunto novo que ele iria iniciar que poderia ajudar na forma independente do aluno escrever. Como por exemplo: Saber fazer as alteraçóes verbais do discurso direto e indireto na produçăo escrita. $\mathrm{O}$ aluno tem que ser capaz de perceber se na frase do discurso direto se o verbo está no presente, neste caso temos um exemplo de discurso direto. No presente 0 fato ocorre simultaneamente ao momento em que se fala. Por exemplo a frase: "Eu adoro camarăo", o verbo adoro está no presente, entăo é, um exemplo de discurso direto. A frase: "Ela adorava camaráo". O Verbo adorava está no pretérito imperfeito, o aluno tem que saber que o verbo no pretérito imperfeito indica que o fato está inacabado, năo totalmente concluído.

$O$ professor começa a atividade escrevendo no quadro as principais alteraçóes verbais que podem ocorrer na mudança do discurso direto e indireto e depois inicia na sala de aula uma explicaçăo sobre o que o aluno precisa fazer para passar do discurso para o indireto. E assim termina a aula.

\section{VERBOS}

Discurso Direto
Presente do Indicativo
O impostor disse:
- Suspeito de todos.

[...] o professor explicou ainda que para saber qual o tipo de discurso é preciso saber o tempo do verbo. No caso posso beber água o tempo verbal está no presente. Entăo é um caso de discurso direto, pois no discurso direto o verbo vem no presente.

\author{
Discurso Inireto \\ Pretérito Imperfeito \\ O impostor disse que suspeitava \\ de todos.
}


Todo o primeiro parágrafo desta passagem, iniciado por uma expressăo atributiva de palavra ("Segundo o professor K") pode ser interpretado como registro do teor das explicaçóes que esse professor fez na aula. Năo se trata, estritamente, de uma passagem em discurso indireto, mas a expressâo "segundo" é suficiente para se compreender que o conteúdo da passagem deve ser atribuído a um "locutor" diferente do narrador geral do relatório. Em algum ponto, no entanto, a redaçăo do parágrafo parece converter-se numa transcriçăo direta das palavras do professor (a partir do segundo período começa-se a ter essa suspeita), o que faria do conjunto do parágrafo uma espécie de discurso indireto livre.

Ocorre que dentro desse parágrafo parece haver diferentes enunciados, com tons, pontos de vista e interlocutores diferentes. Disso suspeitamos pela forma com que os enunciados que imputamos ao "professor K" estăo transcritos. Por exemplo, o primeiro período parece ser um comentário feito pelo professor para o estagiário, provavelmente antes do início da aula, mas o quarto período, que começa com "No presente, o fato ocorre...", já se parece com uma explicaçáo dirigida aos alunos durante a própria aula (o segundo e o terceiro período deixam-nos em dúvida). Em que momento o discurso citado do professor deixou de ser um comentário dirigido ao estagiário e tornou-se uma explicaçâo para toda a classe, se é que se trata disso? Nâo é fácil determinar com clareza.

Podemos entender esse trecho ainda de outro modo: boa parte do parágrafo (do quarto período em diante, talvez incluindo o segundo e até o terceiro período) consistiria em um único comentário do próprio estudante a respeito da afirmaçăo inicial do "professor K.", para quem o domínio dos discursos direto e indireto ajudaria os alunos a escrever melhor. Nesse caso, os exemplos ("saber fazer as alteraçôes verbais..." etc.) seriam acréscimos do estagiário, motivados pelo tema da aula, e năo enunciados efetivamente pronunciados em sala. A relaçâo dialógica entre as "personagens" do estagiário e do professor regente modifica-se por completo de um caso para o outro. Mais do que isso, a forma como se interpreta essa passagem é importante, do ponto de vista de quem orienta o estágio, porque dela depende saber a quem atribuir o imbróglio teórico que encontramos entre tempos verbais e tipos de discurso reportado ("Eu adoro camarăo" vs. "ela adorava camarâo"). A redaçăo do relato năo permite decidir de forma segura a quem atribuir a autoria desses exemplos; ao mesmo tempo, a ambiguidade năo parece ser proposital nem cumprir qualquer efeito estilístico ou retórico.

Há outros elementos de interesse na sequência. O segundo parágrafo da passagem inicia-se com a voz do narrador ("O professor começa a atividade..."). Observe-se agora que o verbo usado por esse narrador ("começa") é um pouco surpreendente, porque, se entendermos que o primeiro parágrafo era o relato de uma explicaçăo do professor aos alunos, somos levados a imaginar que a atividade já estava em andamento e um verbo como "começar" nâo poderia ser usado nesse contexto. Entre esses dois parágrafos, haveria entâo dois relatos alternativos para o mesmo fato - dois inícios de narraçáo organizados conforme pontos de vista ou narradores diferentes. Algo parecido ocorre entre o fim do segundo parágrafo e o trecho que parece ser a transcriçăo do que o "professor K." escreveu na lousa: há um narrador que decreta o término da aula, aparentemente encerrando também o relato, e logo em seguida uma voz que ainda está relatando a aula. Qual é a relaçâo entre quem insere nesse ponto a transcriçăo da lousa e quem disse, logo antes, que a aula acabou? 
Desse ponto em diante, o relatório segue de forma linear, apresentando a transcriçăo de exemplos fornecidos oralmente pelo professor aos alunos, até encerrar-se "pela segunda vez". O que vimos até aqui, em todo caso, é suficiente para relembrar as perguntas que fizemos no início: trata-se de um discurso monológico? Há algum indício de polifonia?

De um lado, temos a impressăo de que é o discurso do "professor $\mathrm{K}$ " que domina o relato da aula e que apenas por conta de escolhas no plano textual sua fala nâo aparece mais claramente como um discurso direto. Ao mesmo tempo, no entanto, há intervençōes inequívocas de um narrador que retira a palavra do "professor K" e parece chamar para si a tarefa de sumarizar a aula, anotando algumas referências temporais ("começa", "termina") que buscam inscrever o discurso desse locutor dentro da unidade englobante que é o próprio relato (exterior às palavras do "professor K").

A impressăo que temos é que, no conjunto do texto, há instâncias discursivas interpoladas de forma que o "diálogo" entre elas năo chega a se concretizar - o que vemos é sempre uma aproximaçăo entre vozes diferentes, mas năo um encontro propriamente dito. Assim, por exemplo, o segundo parágrafo pode ser pensado como um enunciado relativamente autônomo, que corresponderia a um relato sucinto da aula inteira. O primeiro parágrafo parece ser o início de "outro" relato da mesma aula, que avança cronologicamente para além do ponto em que o segundo parágrafo se inicia (daí o estranhamento do verbo "começa"). O mesmo vale para o restante das anotaçóes do aluno, incluindo-se a transcriçăo da lousa que aparece sem nenhuma introduçáo explícita.

Năo nos parece importante levantar a hipótese de que esse efeito resulte de circunstâncias "exteriores" ao trabalho de escrita - por exemplo, que algumas partes do relato foram anotadas em momentos diferentes e depois reunidas às pressas. Ainda que isso possa ter acontecido, o mesmo provavelmente seria válido para qualquer texto, inclusive os romances de Dostoiévski, que nem por isso se apresentam com o mesmo efeito. $O$ que se tem aqui é um tipo de discurso em que diferentes vozes sâo audíveis sem que sejam completamente assimiladas a um ponto de vista monológico, mas também sem que causem um efeito polifônico.

Podemos ressaltar alguns dos traços mais evidentes desse discurso. Um deles é que a entrada de uma nova voz é percebida quase sempre por um estranhamento, náo sobre o ponto de vista trazido por essa voz, mas sobre a própria autenticidade ou integridade do discurso como um todo. Na posiçâo de leitor, oscila-se entre perguntas do tipo "o que será que ele quis dizer aqui?" e questōes como "será que foi isso mesmo que ele quis dizer?", ou ainda "será que é ele mesmo quem está dizendo isso?" Em outras palavras, nessa forma de escrita, a entrada de uma nova voz parece abalar a própria integridade do locutor ${ }^{11}$ a que se vinha atribuindo o discurso. Outra característica é que se trata de um discurso descontínuo - passagens inteiras tornam-se ambíguas ou difíceis de interpretar náo pelo modo como estăo relatadas, mas por conta de um "acidente" na superfície linguística que em geral pode ser localizado de forma bastante precisa - uma palavra fora de lugar, uma mudança de assunto inesperada etc. Enfim,

$11 \quad$ Estamos pensando em "locutor" no sentido que se encontra em Ducrot (1987) - neste caso, nos referimos ao que ele chama de locutor L. 
um terceiro atributo é a impressăo de inacabamento do discurso - tem-se a suspeita de que o enunciado pode náo estar completo ou náo ser ainda definitivo. Talvez se trate de mais de um enunciado: seriam vários, bem ouvidos, mas ainda náo completamente assimilados uns aos outros pelo trabalho de escrita ou de reflexăo daquele que os ouviu; ou inversamente, seria ainda menos que um enunciado: há mais o que se dizer para que o que já foi dito faça sentido, para que tudo "entre nos trilhos" e forme uma composiçâo interpretável. De forma sucinta, é um discurso frente ao qual nossa própria capacidade de formular uma resposta direta (que năo seja uma descriçăo, um comentário como o que fazemos aqui) se vê obnubilada.

Podemos dizer, entăo, que existe um discurso em que as palavras do outro entram mais por um efeito de transcriçâo do que mediadas pela responsividade do falante, colocando nossa própria responsividade em situaçăo difícil. Mesmo no discurso direto, quando se opta por preservar ao máximo o enunciado alheio, há uma escolha que contribui para o efeito geral do enunciado - apresentar um argumento de autoridade, eximir-se do peso de determinadas afirmaçóes etc. Năo é o que se passa em (8). Para caracterizar esse discurso, saímos um pouco do pensamento bakhtiniano e recorremos a uma noçấo oriunda da Psicanálise. Encontramos um conceito de "transcriçầ" que nos interessa em Allouch:

Transcrever é escrever regulando o escrito com base em alguma coisa fora do campo da linguagem. Assim (caso de transcriçấo mais frequente ou, pelo menos, o melhor estudado) o som, reconhecido fora deste campo a partir do momento em que a linguística sabe distinguir entre 'fonética' e 'fonologia'. (ALLOUCH, 1995, p. 15, grifo nosso)

Ao pé da letra, Allouch está nos dizendo que, tendo um bom ouvido, poderíamos "transcrever" uma palestra proferida numa língua que năo falamos ou, para năo ir tăo longe, conseguiríamos escrever sobre um assunto desconhecido repetindo algumas frases de outros lugares com pequenas alteraçôes sintáticas. Allouch nâo se refere apenas à transcrição como um ato concreto, no entanto - há transcriçăo, por exemplo, na fala de uma criança que repete por prazer uma frase ouvida do adulto, ou em um traço de estilo que favorece a repetiçāo de certas palavras. A transcriçâo é, para Allouch, um trabalho mediado pelo real, no sentido lacaniano, assim como a traduçāo é mediada pelo imaginário e a transliteraçāo, pelo simbólico. Um aspecto importante dessa proposiçăo é que, em se tratando do real, a transcriçăo năo é orientada pelo sentido e o seu produto náo é uma compreensáo -năo estamos falando, portanto, de uma escuta racionalizada ou de uma escrita parafrástica. De outro lado, a transcriçáo também nâo é orientada pelo inconsciente (ou pela ideologia, como se discutiu na Análise do Discurso), de modo que também năo se trata de pensar numa reproduçâo involutária das determinaçōes simbólicas do sujeito.

A transcriçâo corresponde a uma forma específica de suscetibilidade à palavra do outro, tomada fora da linguagem. Isso significa dizer que se pode escutar o enunciado de outrem, primeiro, sem entendê-lo - sem que ele se converta em qualquer tipo de material semântico parafraseável, com o qual se concorde ou discorde etc. - e segundo, sem que ele tenha sobre quem escuta um efeito "refratário" ou "ideológico" - sem posicionar o sujeito dentro de uma estrutura ou rede simbólica, invisível para si, mas descritível por meio de algum tipo de análise. Na transcriçăo, o enunciado apenas persiste, ficando à disposiçâo da memória ou dos olhos, mantendo-se suscetível a efeitos 
futuros que o reintroduzirâo no campo "semiológico" propriamente dito (a descoberta de um enunciado semelhante, a associaçấo casual com outro enunciado, uma tardia explicaçâo e assim por diante).

Bakhtin năo levanta a hipótese, embutida na consideraçăo do real de Lacan, de que o aspecto dialógico da linguagem possa ser "suspenso", por assim dizer, e o signo venha a ser apreendido de outra forma que năo como signo. ${ }^{12}$ É apenas por isso que diferenciamos a "transcriçăo" daquilo que normalmente se nomeia como responsividade, que parece implicar sempre a inscriçâo da resposta a um enunciado numa série histórica (portanto, simbólica).

Enfim, para tirarmos daí uma conclusăo, se a polifonia consiste em um discurso no qual as relaçóes dialógicas entre duas consciências irredutíveis podem ser percebidas em ato, o discurso pautado pela transcriçăo pode ser considerado um discurso "cacofônico". O que o caracteriza năo é nem a existência de uma única voz, nem o efeito "harmônico" de diferentes vozes combinadas, mas o fato de que algumas vozes se sobrepóem sem que a soma delas resulte em um acabamento unitário ao qual se possa produzir uma resposta direta - delas se ouve o ruído sobreposto e o tempo desencontrado.

Essa lógica parece reger ao menos algumas passagens dos textos que temos colhido em nossa pesquisa de campo; talvez ela seja estimulada pela própria exigência de que os relatos sejam feitos de forma detalhada. Pode-se interpretá-la, em parte, como resultado de circunstâncias bem conhecidas, como a dificuldade de se organizar uma quantidade grande de informaçôes ou a pouca habilidade dos estudantes com a releitura e reescrita dos próprios textos. Esses problemas, no entanto, a nosso ver náo explicam o discurso "cacofônico" em si, mas apenas por que ele se torna visível com tanta frequência, aparecendo na versâo final do texto entregue ao supervisor em vez de ser apagada em alguma etapa prévia.

A "cacofonia" pode representar um obstáculo se consistir num posicionamento estabilizado - estaríamos falando de uma disposiçáo do sujeito para substituir o esforço de interpretaçăo dos dados pela precisăo do seu registro. A ideia de uma observaçăo reflexiva estaria sendo substituída, desse modo, por uma concepçâo da prática como testemunho direto. Uma das razóes para que a "cacofonia" apareça nos textos talvez seja que os estagiários a valorizam como indício dessa suposta imediatez da experiência $^{13}$ - mais do que "tergiversar" sobre a aula, contaria a seu favor comprovar que se "esteve lá". Voltamos assim à concepçâo de prática de que falamos no início do trabalho.

Podemos imaginar, no entanto, ao menos uma situaçăo em que um ouvido atento ao "cacofônico" pode ser desejável. Nem sempre convém que o pesquisador compreenda o dado que está registrando, ao menos no momento em que o registra; pelo contrário,

12 Encontra-se a discussâo inversa: corpos físicos, instrumentos e produtos de consumo sâo realidades a princípio externas ao signo que podem tornar-se signo (um martelo pode simbolizar o trabalho, o páo e o vinho simbolizam Cristo). Nas palavras do autor, "[...] ao lado dos fenômenos naturais, do material tecnológico e dos artigos de consumo, existe um universo particular, o universo dos signos" (BAKHTIN, 2004, p. 32). Nâo há, no entanto, uma problematizaçăo do signo percorrendo o caminho inverso e sendo tomado fora da ideologia.

13 E em certo sentido ela é mesmo uma virtude do texto: quando se suspeita de que há fraude e o estagiário nâo cumpriu todas as atividades que relata, a presença de trechos "cacofônicos" pode ser um indício de veracidade, já que dificilmente um documento forjado reproduziria esse tipo de "problema" - sâo as unhas e orelhas de Morelli (GINZBURG, 1989). 
se o dado já está interpretado ao ser coletado, pode-se suspeitar que ele está sendo coletado unicamente por essa razăo. Para que a escrita nos estágios se torne produtiva, com efeito, os estudantes nâo deveriam ser colocados exclusivamente em busca de dados previsíveis. Uma escrita investigativa exigiria, pelo menos em alguns momentos, a suspensăo do conhecimento prévio que tem sobre a escola (formado inclusive nas leituras e debates que se fazem na universidade) e o exercício de uma escuta voltada para aquilo sobre o que ainda năo se falou. Năo há dúvida de que o que se escuta aí pode soar inconveniente ou simplesmente incompreensível - pôr-se à escuta dos ruídos, nesse caso, é de grande importância.

Enfim, para sumarizar o que dissemos, há momentos de "hesitaçâo" na escrita que podem mostrar (inclusive a quem escreveu) pontos de contradiçăo em uma linha de pensamento inicialmente assumida, como vimos no item anterior. De forma semelhante, os dados coletados de forma "cacofônica" podem resultar em achados mais valiosos do que os que se faria se a intençăo for apenas confirmar hipóteses prévias e garantir o "bom acabamento" do discurso monológico. Essas consideraçôes săo válidas, contudo, na medida em que se entenda que estamos falando de um processo de escrita e năo do aspecto final que os textos eventualmente têm que assumir. $O$ fato de que percebamos essas características em relatórios entregues pelos estudantes sinaliza onde estâo os pontos sobre os quais seu trabalho poderia continuar.

\section{CONSIDERAÇÕES FINAIS}

Para encerrar, retomamos as três perguntas que foram lançadas no início e procurando explicitar as respostas que encontramos a elas no percurso de análise empreendido aqui.

A primeira pergunta era - pode-se encontrar polifonia (no sentido bakhtiniano) em relatórios de estágio? Para isso, somos levamos a responder, ao menos por ora, que náo. Há casos como os trechos analisados em (5), (6) e (7), que podemos analisar como sendo discursos bivocais, mas eles năo dăo o tom do corpus e săo passagens que consideramos excepcionais. Na medida em que Bakhtin usa o termo "polifonia" para referirse ao atributo de uma "poética" - isto é, a um trabalho do autor sobre a linguagem para representar o real -, nos vemos propensos a dizer que as formas preferidas de escuta e expressâo da aula na escrita acadêmica privilegiam os discursos de tipo monológico como ideal.

A segunda pergunta era - como se pode caracterizar, dialógica ou enunciativamente, a prosa de relatórios de estágios nos casos em que ela năo é nem polifônica, nem monológica? Para isso, demos uma reposta: trata-se de uma escrita "cacofônica". Em vez de escrever, transcreve-se - capturam-se, com isso, traços do discurso do outro diretamente pelo "real", mas nâo se estabelece com eles uma relaçấo dialógica consistente. Podem-se obter bons dados dessa forma (nem sempre), mas a condiçăo para analisá-los nâo está garantida no fato de se conseguir coletá-los. Isso nos leva a dizer que, se o relatório é uma ferramenta formativa, a exigência de registros minuciosos da aula tem que vir acompanhada por recortes seletivos, pertinentes e "responsivos" - em outras palavras, é preciso que o detalhe captado pelo aluno resulte de uma escolha e năo apenas de uma persistência dos ouvidos. Se isso năo for feito, o trabalho de campo 
pode se tornar uma atividade mecânica e ser vivenciado, inclusive, como dispensa da reflexăo e do compromisso intelectual com as práticas.

A terceira pergunta era, enfim: de que maneiras o manejo da polifonia na escrita está relacionado à construçâo de compreensóes da própria "realidade de ensino" que é o referente do discurso? Obviamente năo há relaçōes diretas entre uma coisa e outra. Esperamos estar contribuindo para mostrar uma forma de aproximaçáo do problema. Vimos que a escrita de relatórios privilegia formas monológicas do discurso e um estilo aparentemente avesso ao discurso reportado. Uma fórmula para expressar sinteticamente no que esse estilo consiste seria: a aula tende a ser vista como objeto de conhecimento e nâo como objeto de discurso. Isto é, tende a ser vista como objeto dotado de um conjunto de características que precedem a observaçáo e independem do fato de se usar a língua para descrevê-las - assim, as falas escutadas no trabalho de campo săo percebidas como evidência de uma realidade objetiva anterior e năo como parte dos atos que produzem a própria aula. Essa percepçăo objetivada da aula tende a obscurecer as relaçóes dialógicas entre os enunciados manifestados na aula e, talvez de forma mais acentuada, as relaçôes dialógicas implícitas desses enunciados com outros que conectam as açóes didáticas em sala com discursos de circulaçâo mais ampla (legislaçấo e políticas educacionais, teorias da linguagem e propostas de ensino etc.).

Acreditamos que é melhor, ao menos para o professor de língua, que a aula seja percebida e representada como objeto de discurso antes de se tornar objeto de conhecimento. Em primeiro lugar, porque a própria formaçăo em língua o instrumentaliza a descrever a aula a partir dessa perspectiva. Em segundo lugar, porque, assumindo-se como alguém habilitado a dizer o que é uma aula e como ela funciona, o professor se assume ao mesmo tempo como participante dos processos sociais pelos quais uma aula se torna o que é. 


\section{REFERÊNCIAS}

ALLOUCH, J. Letra a letra. Transcrever, traduzir, transliterar. Traduçâo de Dulce Duque Estrada. Rio de Janeiro: Campo Matêmico, 1995.

APPLE, Michael. Educaçăo e poder. Traduçăo de Maria Cristina Monteiro. Porto Alegre: Artes Médicas, 1989.

BAKHTIN, M. Problemas da poética de Dostoiévski. Traduçâo de Paulo Bezerra. 5. ed. Rio de Janeiro: Forense, 2015.

Marxismo e filosofia da linguagem. Traduçâo de Michel Lahud e Yara Frateschi Vieira. 11. ed. Săo Paulo: Hucitec, 2004.

BRASIL. Ministério da Educaçăo. Conselho Nacionalde Educaçăo. Diretrizes Curriculares. Resoluçâo n. 2 de $1^{\circ}$ de julho de 2015. Define as diretrizes curriculares nacionais para a formaçâo inicial em nível superior (cursos de licenciatura, cursos de formaçâo pedagógica e cursos de segunda licenciatura) e para a formaçăo continuada.

DERRIDA, J. Força e significaçăo. In: A escritura e a diferença. Sâo Paulo: Perspectiva: 2011, pp. 1-41.

DUCROT, O. Esboço de uma teoria polifônica da enunciaçăo. In: 0 dizer e o dito. Campinas: Pontes, 1987, pp. 161-218.

FAIRCHILD, T. M. Quatro consideraçóes sobre a leitura de relatórios de estágio em Língua Portuguesa. In: Krause-Lemke, C. et. al. (Org.). Cultura, linguagem e educaçăo: relaçōes de poder. Guarapuava: UNICENTRO, 2008, pp. 227-249.

GERALDI, J. W. A aula como acontecimento. In: A aula como acontecimento. Săo Carlos: Joăo \& Pedro Editores, 2010, p. 81-93.

GINZBURG, C. Mitos, emblemas, sinais. Morfologia e história. Traduçáo de Federico Carotti. 2. ediçâo. Sáo Paulo: Companhia das Letras, 1989.

KNAPP, E. Após pressăo, formaçăo de professor terá menos teoria e mais prática. Folha de Săo Paulo, Sáo Paulo, 17 de agosto de 2012. Caderno Educaçăo. Disponível em <https:// www.google.com.br/?gfe_rd=cr\&ei=Hn03VrrWIOWU8QfOgIFA\&gws_rd=ssl\# q=conselho+estadual+de+educa\%C3\%A7\%C3\%A3o+s\%C3\%A3o+paulo+menos+teoria>. Acesso em: 20 nov. 2015.

MAINGUENEAU, D. Gênese dos discursos. Traduçâo de Sírio Possenti. Săo Paulo: Parábola, 2008.

PÊCHEUX, M. Semântica e discurso. Uma crítica à afirmaçâo do óbvio. Traduçâo de Eni Pulcinelli Orlandi [et al.]. 2. ed. Campinas: Unicamp, 1995.

PIETRI, E.; CHAMPOUDRY, A. C. As disciplinas de formaçâo de professores de Língua Portuguesa e a flexibilizaçăo curricular. In: SAMPAIO, M. L. P.; REZENDE, N. L.; BONFIM, M. N. B. (Orgs.). Ensino de língua portuguesa. Entre documentos, discursos e práticas. Sâo Paulo: Humanitas, 2012, pp. 213-235.

RIOLFI, C. R. Liçôes da coragem: o inferno da escrita. In: RIOLFI, C. R. e BARZOTTO, V. H. (Orgs.) 0 inferno da escrita. Produçấo escrita e psicanálise. Campinas: Mercado de Letras, 2011, pp. 11-31. 